\title{
PENANGGULANGAN GELANDANGAN DAN PENGEMIS OLEH PANTI SOSIAL BINA KARYA “PANGUDI LUHUR” BEKASI
}

\author{
Oleh: \\ Betha Dwidinanti Zefianningsih, Budhi Wibhawa, \& Hadiyanto A. Rachim \\ E-mail: \\ bdwidinanti@gmail.com
}

\begin{abstract}
ABSTRAK
Permasalahan gelandangan dan pengemis masih menjadi beban pembangunan nasional dewasa ini. Maka dari itu, peran pemerintah dan masyarakat untuk menanggulangi permasalahan ini tentunya harus dilakukan secara bersama-sama sehingga mampu mengurangi kesenjangan sosial yang ada. Gelandangan dan pengemis merupakan kantong kemiskinan yang hidup diperkotaan. Hal ini disebabkan karena faktor ekonomi dan kebutuhan hidup yang semakin mendesak. Penertiban gelandangan dan pengemis (gepeng) memerlukan waktu yang cukup lama dalam penanganannya. Hal ini dikarenakan terkadang pada waktu tertentu populasi pengemis meningkat seperti yang terjadi dihari libur, hari raya keagamaan, maupun dipusat-pusat rekreasi dan perbelanjaan. Tentunya secara grafik digambarkan jumlah populasi pengemis mengalami kenaikan dan penurunan.

Penyebab kesenjangan yang besar adalah faktor ekonomi yang tidak merata sehingga jurang sosial antara si kaya dan si miskin tinggi terutama dikota-kota besar. Oleh karena itu, pemecahan masalahnya harus mencakup dua aspek yaitu: (i) kondisi di daerah asal; (ii) kondisi daerah tujuan. Prinsipnya adalah upaya pencegahan dilakukan di daerah asal sehingga mereka tidak terdorong untuk meninggalkan desanya dan mencari penghasilan di kota dengan cara membuka pekerjaan di desa. Sedangkan di sisi lain, prinsipnya adalah penanggulangan yaitu di tempat tujuan "harus" ditanggulangi atau ditangani sehingga mereka tidak lagi tertarik untuk menjadi Gepeng di kota, karena tidak akan memperoleh penghasilan lagi.
\end{abstract}

Kata Kunci: Gelandangan, Pengemis, Kesenjangan Sosial, Penanggulangan.

\section{PENDAHULUAN}

Kota merupakan suatu wilayah yang pemukimannya relatif besar, padat dan permanen, serta dihuni oleh orang-orang yang heterogen kedudukan sosialnya. Keadaan tersebut didukung karena perkotaan merupakan pusat perekonomian, kebudayaan, politik dan pemerintahan sehingga banyak masyarakat yang berdatangan ke kota bahkan menetap. Pesatnya pertumbuhan penduduk di perkotaan tidak seimbang dengan ruang yang ada dan peluang pekerjaan di perkotaan. Hal inilah yang akan menjadi permasalahan di kota.

Persaingan hidup yang keras di perkotaan, membuat mereka yang tidak memiliki keterampilan ataupun tingkat pendidikan yang tinggi akan kehilangan peluang untuk mendapatkan penghidupan sebagaimana mestinya. Wilayah perkotaan tidak terlepas dari masalah kemiskinan. Kemiskinan merupakan keadaan dimana seseorang atau kelompok yang tidak mampu memenuhi kebutuhan hidupnya. 
Ketidakmampuan seseorang dalam pemenuhan kebutuhannya bisa disebabkan karena keadaan fisik yang cacat, keterampilan terbatas, pendidikan yang rendah, bahkan tidak adanya ruang gerak bagi mereka untuk berkreasi dan berinovasi. Keadaan seperti ini yang menjadi lingkaran tak berujung bagi masyarakat miskin. Tidak adanya kesempatan bagi mereka untuk memiliki ruang gerak mengakibatkan mereka menjadi manusia yang tidak produktif. Hasilnya mereka akan tetap berada pada garis kemiskinan, bahkan mereka lebih memilih hidup menggelandang dari meminta-minta. Masalah seperti ini bukanlah masalah baru melainkan masalah yang sudah menjamur.

Homeless atau gelandangan adalah orang-orang yang hidup dalam keadaan tidak sesuai dengan norma kehidupan yang layak dalam masyarakat setempat, serta tidak mempunyai tempat tinggal dan pekerjaan yang tetap di wilayah tertentu dan hidup mengembara di tempat umum. Sedangkan pengemis adalah orang-orang yang mendapatkan penghasilan dengan memintaminta di muka umum dengan pelbagai cara dan alasan untuk mengharapkan belas kasihan dari orang lain.

Ciri-ciri homeless:

a) Para tunawisma tidak mempunyai pekerjaan;

b) Kondisi fisik para tunawisma yang dapat dibilang tidak sehat karena kondisi lingkungan yang memprihatinkan;

c) Para tunawisma biasanya mencaricari barang atau makanan disembarang tempat demi memenuhi kebutuhan hidupnya; dan

d) Para tunawisma hidup bebas, tidak bergantung kepada orang lain ataupun keluarganya.

Kategori tunawisma:
1) Tunawisma biasa, yaitu mereka mempunyai pekerjaan namun tidak mempunyai tempat tinggal tetap;

2) Tunakarya, yaitu mereka yang tidak mempunyai pekerjaan dan tidak mempunyai tempat tinggal tetap; dan

3) Tunakarya cacat, yaitu mereka yang tidak mempunyai pekerjaan dan tidak mempunyai tempat tinggal, juga mempunyai kekurangan jasmani dan rohani.

Alasan utama dan penyebab tunawisma banyak didokumentasikan dalam studi, meliputi:

- Tidak tersedianya lapangan kerja;

- Kemiskinan; disebabkan oleh banyak faktor termasuk pengangguran dan setengah pengangguran

- Orang yang memiliki beberapa jenis penyakit kronis dan melemahkan tetapi tidak bisa mendapatkan layanan kesehatan baik karena mereka tidak punya uang untuk membelinya atau karena pemerintah tidak akan memberikannya kepada mereka terlalu lemah untuk pergi dan bekerja setiap hari sehingga mereka tetap miskin dan tunawisma;

- Penyalahgunaan kekuasaan oleh pemerintah maupun orang lain;

- Perang atau konflik bersenjata;

- Gangguan mental, dimana layanan kesehatan mental tidak tersedia;

- Cacat, terutama dimana pelayanan penyandang cacat atau miskin bermasalah;

- Pengecualian sosial, termasuk karena orientasi seksual dan identitas gender;

- Kekerasan domestik;

- Hubungan kerusakan, terutama dalam kaitannya dengan orang-orang muda dan orang tua mereka; 
- Penjara rilis dan masuk kembali ke dalam masyarakat;

- Bencana, termasuk namun tidak terbatas pada gempa bumi dan badai;

- Penggusuran paksa, banyak negara orang kehilangan rumah untuk memesan membuat jalan bagi yang lebih baru kelas bangunan, jalan raya bertingkat, dan lainnya. Kebutuhan kompensasi tersebut mungkin minimal, namun tidak dapat menemukan perumahan baru bagi tunawisma;

- Penyitaan, karena penggadaian dimana pemegang gadai melihat solusi terbaik untuk pinjaman ini ialah untuk mengambil dan menjual rumah untuk melunasi hutang;

- Penyitaan pada tuan tanah sering menyebabkan penggusuran dari penyewa mereka;

- Kriminalitas. Beberapa orang dari tunawisma merupakan pelaku tindak kejahatan dan dilakukan secara sembunyi-sembunyi dari pihak yang berwenang;

Terdapat beragam alasan yang menjjadikan seseorang atau lansia memilih untuk menjalani hidupnya sebagai seorang tunawisma. Mulai dari permasalahan psikologis, kerenggangan hubungan dengan orang tua, atau keinginan untuk hidup bebas. Namun alasan yang paling banyak dan umum ialah kegagalan para perantau dalam mencari pekerjaan;

Cerita-cerita di kampung halaman terkait kesuksesan perantau kerap menjadi buaian bagi putra daerah untuk turut meramaikan persaingan di kota besar. Beberapa diantaranya memang berhasil, namun kebanyakan dari perantau kurang menyadari bahwa keterampilan yang mumpuni ialah modal utama dalam perantauan. Sehingga mereka yang gagal dalam merengkuh impiannya melanjutkan hidupnya sebagai tunawisma karena merasa malu apabila ia pulang ke kampung halamannya; dan Masalah kependudukan di Indonesia pada umumnya telah lama membawa masalah yang berkelanjutan, yaitu penyediaan lapangan pekerjaan. Apabila kita meninjau keadaan saat ini, pemerataan lapangan pekerjaan di Indonesia dirasa masih sangat kurang. Sehingga kota besar pada umumnya mempunyai lapangan pekerjaan yang lebih banyak dibandingkan dengan kota-kota kecil.

Hal inilah yang menjadi penyebab keengganan tunawisma untuk kembali ke daerahnya selain karena perasaan malu karena berpikir bahwa daerahnya memiliki lapangan pekerjaan yang lebih sempit daripada tempat dimana mereka tinggal sekarang. Mereka memutuskan untuk tetap meminta-minta, mengamen, memulung dan berjualan sedanya hingga pekerjaan yang lebih baik menjemput mereka. Selain itu, masalah yang hingga saat ini belum teratasi yaitu kemiskinan yang sangat mempengaruhi munculnya tunawisma pada lansia. Permasalahan yang sangat dirasakan oleh kaum miskin yaitu permasalahan sosial ekonomi mereka, yakni karena mereka tidak mempunyai ekonomi yang cukup, maka mereka tidak bisa membeli rumah sehingga mereka memutuskan untuk menjadi tunawisma (gelandangan).

Salah satu penyebab mengapa tunawisma di permasalahkan yaitu karena kebanyakan para tunawisma itu tinggal di pemukiman kumuh dan liar, menempati zonazona publik yang sebenarnya melanggar hukum, dengan cara mengontak petak-petak di daerah kumuh di pusat kota atau mendiami stren-stren kali sebagai pemukim liar.

Persoalan dalam lingkup masyarakat yang berhubungan dengan homeless dalam berbagai pendapat:

- Di kota-kota besar, para tunawisma memadati lampu merah, emperan took dan kawasan tertentu sehingga menjadi fenomena tersendiri di dalam kehidupan sosial perkotaan di Indonesia. 
- Di negara kapitalis maju, pengangguran dipicu oleh pengurangan jam kerja dan jumlah tenaga kerja yang dibutuhkan akibat penerapan mekanisasi dan teknologi modern di sektor industry. Sementara di negara berkembang, pemicu utama pengangguran adalah gejala deindustrialisasi akibat proyek neoliberal.

- Dampak secara fisik dari tunawisma:

- Kebersihan dan kesehatan. Perilaku hidup bersih mereka masih sangat kurang. Ventilasi dan penerangan juga masih kurang yang menyebabkan munculnya berbagai masalah kesehatan. Mereka tidak mempunya dana yang cukup untuk memelihara kesehatan dan pengobatan mereka sendiri.

- Gizi kurang. Mereka tidak mampu memenuhi kebutuhan pangan akibat rendahnya daya beli makan, terutama makanan bergizi. Hal inilah yang mengakibatkan mereka mengalami gizi buruk termasuk ibu hamil dan balita.

- Tindak kekerasan sesame tunawisma. Perebutan atau persaingan lahan pencari makan menyebabkan mereka berkonflik.

- Pengguna narkoba. Banyak diantara mereka mengkonsumsi narkoba. Hal ini disebabkan oleh lingkungan tempat tinggal mereka. Mereka rawan terkena HIV/AIDS dengan penggunaan jarum suntik secara bergantian.

- Dimanfaatkan. Banyak anak-anak kecil yang dimanfaatkan untuk mengemis dan menyetorkan sejumlah uang setiap harinya agar terhindar dari tindak kekerasan oleh pihak lain yang lebih kuat atau oleh orang dewasa yang tidak bertanggung jawab.

- Pelecehan seksual. Orang dewasa tidak bertanggung jawab melakukan sodomi, pelecehan seksual dengan imbalan uang atau dibawah ancaman mereka untuk melampiaskan nafsu mereka

Dampak adanya tunawisma terhadap lingkungan:

- Lingkungan kota menjadi kumuh dan kotor;

- Banjir karena terhambatnya fungsi sungai tersebut; dan

- Maraknya tindak kriminalitas dalam pemenuhan kebutuhan hidupnya.

Adanya pengemis juga cukup meresahkan masyarakat. Banyak yang menganggap bahwa adanya gelandangan dan pengemis sangat mengganggu masyarakat. Keberadaan mereka bisa saja mengakibatkan masalah kejahatan (kriminal). Dari masalah-masalah inilah yang nantinya keberadaan mereka benar-benar tidak diharapkan oleh masyarakat luas.

Sebagaimana kita ketahui, sebagian besar masyarakat desa berpikiran bahwa dengan hidup di kota akan merubah nasib mereka. Hal ini akan terlaksana jika kita memiliki keterampilan. Namun, banyak orang yang tidak memiliki keterampilan tetap nekad untuk pergi ke kota (urbanisasi). Jika pemikiran ini tidak segera di ubah, tentu saja setiap hari akan semakin banyak masyarakat tanpa keahlian di kota yang berpotensi sebagai tunawisma.

Alhasil, tunawisma akan semakin banyak dan membuat kota semakin terlihat kumuh. Dari kekumuhan itu, akan menyebabkan masalah baru seperti banyaknya wabah penyakit, bencana dan juga tingginya tingkat kriminalitas. Dari wabah penyakit tentu saja akan menyebabkan lingkungan menjadi tidak bersih dan berpotensi besar pertumbuhan nyamuk. Malaria, demam berdarah, dan cikungunya pun akhirnya akan menjadi makanan sehari-hari mereka dan angka kematian pun akan menjadi semakin besar.

Gizi yang mereka dapatkan pun hampir nol. Hal ini disebabkan ketidakmampuan mereka dalam membeli bahan makanan 
dengan mutu yang berkualitas. Anak-anak yang diharapkan sebagai generasi penerus bangsa sama sekali tidak mengenyam pendidikan dan malah mengemis kesana kemari.

\section{KAJIAN PUSTAKA}

Permasalahan tunawisma sampai saat ini merupakan masalah yang tidak ada habishabisnya, karena berkaitan satu sama lain dengan aspek-aspek kehidupan. Namun pemerintah juga tidak habis-habisnya berupaya untuk menanggulanginya. Dengan berupaya menemukan motivasi melalui persuasi dan edukasi terhadap tunawisma supaya mereka mengenal potensi yang ada pada dirinya, sehingga tumbuh keinginan dan berusaha untuk hidup lebih baik.

Penanggulangan tunawisma dilakukan melalui beberapa tahapan, yaitu:

- Tahap persiapan

Tunawisma biasanya tidak mempunyai tempat tinggal, maka suatu hal yang esensial bila mereka ditanggulangi dengan memotivasi mereka untuk bersama-sama dikumpulkan dalam suatu tempat. Tahap ini bertujuan untuk berusaha memasuki atau mengenal aktivitas atau kehidupan para tunawisma.

- Tahap penyesuaian diri

Setelah para tunawisma dikumpulkan, maka mereka harus belajar untuk menyesuaikan diri mereka pada lingkungannya yang baru dimana berlaku aturan-aturan khusus. Agar nantinya mereka lebih disiplin dan teratur.

- Tahap pendidikan yang berkelanjutan

Setelah para tunawisma diadakan evaluasi mengenai potensi yang mereka miliki untuk belajar dengan maksud supaya mendapatkan pendidikan yang lebih layak.

Dengan mekanisme yang lebih menyentuh pada permasalahan dasar para tunawisma, diharapkan tunawisma di kota besar dapat teratasi tanpa menciderai hak-hak individu mereka dan malah dapat membawa para gelandangan kepada kehidupan yang lebih baik. Namun, mekanisme di atas merupakan tindakan jangka panjang yang membutuhkan waktu yang lama untuk dapat terealisasi. Untuk itu, diperlukan kerjasama yang baik antar generasi kepemerintahan agar hal tersebut dapat terwujud dan pada akhirnya kesejahteraan bangsa dapat lebih mudah dicapai. Dan tentunya mekanisme tersebut harus dilakukan secara terus menerus dan paling tidak berangsur agar hasil yang dicapai dari mekanisme tersebut akan sesuai harapan baik pemerintah maupun tunawisma itu sendiri.

Namun masih ada kendala dalam penanganan homeless. Kendala-kendala tersebut ialah:

a) Alokasi dana untuk penanganan tunawisma relatif kecil;

b) Upaya penanganan terhadap tunawisma seringkali hanya berhenti di pendekatan punitive-represif;

c) Upaya penanganan sering tidak didukung oleh kebijakan Pemerintah Daerah (PEMDA);

d) Kurangnya partisipasi dan perhatian dari pemerintah; dan

e) Belum teratasinya kemiskinan.

Kebijakan yang dilakukan pemerintah, khususnya Pemerintah Daerah (PEMDA) selama ini cenderung kurang menyentuh stakeholdernya, atau pihak-pihak yang terkait dengan permasalahan dalam peraturan. Mekanisme yang saat ini dijalankan adalah dibangunnya Panti Sosial untuk tunawisma (gelandangan). Namun, efektifitasnya dirasa kurang karena Panti Sosial ini sebenarnya belum menyentuh permasalahan yang sebenarnya dari para tunawisma, yaitu keengganan untuk kembali ke kampong halaman. Sehingga yang terjadi di dalam praktek pembinaan sosial ini ialah para tunawisma yang keluar masuk panti sosial.

Menurut saya, untuk mengatasi para tunawisma yaitu dengan cara menyediakan tempat/panti rehabilitasi dimana diajarkan 
keterampilan-keterampilan, seperti menjahit, memasak, dll. Lalu dengan bekal keterampilan tersebut, diharapkan mereka akan dapat diterima bekerja sesuai dengan keterampilan mereka masing-masing.

Transmigrasi juga snagat penting karena pulau-pulau Indonesia masih sangat luas dan banyak. Di pulau-pulau itulah mereka pasti akan lebih sejahtera karena banyaknya sumber daya alam yang belum dimanfaatkan dengan baik. Di sanalah kita melihat, jika ingin merubah nasib.

Sedangkan untuk mencegah agar jumlah tunawisma tidak semakin banyak, pemerintah harus menyediakan lapanganlapangan kerja di kota-kota kecil. Hal ini dimaksudkan untuk meminimalisir arus urbanisasi yang berujung pada tunawisma.

Berdasarkan uraian di atas, peneliti bermaksud melakukan penelitian untuk mengetahui lebih jauh tentang faktor penyebab terjadinya gelandangan dan pengemis dengan mengambil studi penanggulangan gelandangan dan pengemis yang dilakukan oleh Panti Sosial Bina Karya "Pangudi Luhur" Bekasi. Ramainya kota ini bisa mereka jadikan sebagai lading mata pencaharian bagi para pengemis. Banyaknya ruko-ruko atau toko yang berdiri di daerah ini bisa dijadikan sebagai tempat berteduh atau tidur bagi para gelandangan. Sehingga besar kemungkinan ditemukannya para gelandangan dan pengemis di tempat ini.

Perilaku menggepeng erat kaitannya dengan urbanisasi, dan urbanisasi erat kaitannya dengan adanya kesenjangan pembangunan wilayah pedesaan dan perkotaan. Semasih adanya kesenjangan ini, maka urbanisasi akan sulit dibendung dan akan memberi peluang munculnya kegiatan sektor informal seperti kegiatan menggepeng.

Pada hakikatnya, tidak ada norma sosial yang mengatur perilaku menggepeng. Kegiatan menggepeng umumnya dilakukan ibu-ibu yang disertai anaknya. Mereka umumnya relative muda dan termasuk dalam tenaga kerja yang produktif. Pendidikan keluarga gepeng pada umumnya rendah. Hal ini disebabkan sulitnya masyarakat miskin dalam mengakses pendidikan, juga termasuk karena anak usia sekolah terpaksa menggelandang dan mengemis untuk memenuhi kebutuhan hidupnya. Akhirnya kebodohan dan kemiskinan pun seakan menjadi sebuah turunan pada keluarga tersebut. Adanya peran aktif dari berbagai kalangan dalam hal ini dalam pengentasan kemiskinan dan juga masalah gelandangan dan pengemis ini.

Ada beberapa langkah yang mungkin dapat diterapkan antara lain adalah tetap menertibkan para gelandangan-gelandangan dan pengemis tersebut dan berusaha untuk mengembalikan mereka ke kampong halamannya. Berikutnya ialah mengembangkan usaha-usaha dari desa asal agar tidak terulang permasalahan tersebut, atau dengan kata lain tidak membuat semacam ketimpangan pembangunan antara kota dan desa. Pemenuhan kebutuhan spiritual untuk memelihara sikap idealis yang sudah ada di masyarakat.

\section{Proses Pemberdayaan Gelandangan dan Pengemis}

Pemberdayaan gelandangan dan pengemis yang dilakukan oleh pihak dinas sosial bersifat kompleks, artinya bahwa sebelum diadakannya pelatihan para gepeng terlebih dahulu diberikan bimbingan-bimbingan, serta pelatihan keterampilan yang prosesnya adalah sebagai berikut :

\section{Bimbingan mental}

Bimbingan mental ini dilakukan secara intensif oleh pihak dinas sosial kepada para PMKS. Bagian ini merupakan bagian yang sangat penting guna menumbuhkan rasa percaya diri serta spiritualitas para gelandangan dan pengemis. Karena pada dasarnya mereka memiliki semangat dan rasa percaya diri yang selama ini tersimpan jauh di dalam dirinya. Selain itu mereka juga mempunyai potensi yang cukup besar, hanya saja belum memiliki penyaluran atau 
sarana penghantar dalam memanfaatkan potensi-potensi tersebut.

Pada saat pertama kali para gelandangan dan pengemis (gepeng) yang tercakup dalam razia, keadaan mereka sangat memprihatinkan, ada yang memasang muka memelas ada juga yang dengan santainya mengikuti semua proses dalam therapy ini, dalam therapy individu dilakukan pengecekan terhadap semua gelandangan dan pengemis (gepeng) satu persatu secara psikis.

\section{Bimbingan kesehatan}

Sebelum pihak dinas kesehatan melakukan bimbingan kesehatan, terlebih dahulu para penyandang masalah kesejahteraan sosial (PMKS) diberikan fasilitas penanganan kesehatan yaitu pemeriksaan kesehatan bagi mereka yang sedang sakit. Kemudian kegiatan bimbingan kesehatan dimulai dengan penyadaran tentang pentingnya kesehatan badan atau jasmani. Mulai dari hal kecil seperti pentingnya mandi, gosok gigi dan memakai pakaian bersih. Melihat selama ini kehidupan di jalanan yang sangat keras dan serba tidak sehat, para gelandangan dan pengemis (gepeng) tentu masih merasa kesulitan untuk menerapkan gaya hidup sehat sehingga apa yang diperoleh dalam bimbingan kesehatan tidak diterapkan sepenuhnya dalam kehidupan mereka.

\section{Bimbingan ketertiban}

Bimbingan ketertiban ini diisi oleh Satpol PP yang dilakukan 1 bulan sekali, dengan tujuan memberikan pengarahan tentang tata tertib lalu lintas, serta peraturan di jalan raya, sehingga para gelandangan dan pengemis tidak lagi berkeliaran dijalan raya, karena keberadaan mereka di jalanan sangat mengganggu keamanan serta ketertiban lalu lintas.

Dalam proses bimbingan ketertiban ini biasanya pihak dinas sosial mendatangkan narasumber dari Satpol PP atau pihak kepolisian setempat. Menurut pengamatan peneliti pada saat pertama mengikuti wejangan dari pak polisi para gelandangan dan pengemis (gepeng) terlihat sangat antusias. Mungkin mereka takut berhadapan dengan polisi, karena pada dasarnya para gelandangan dan pengemis (gepeng) dijalanan sangat berhati-hati terhadap polisi, takut ditangkap dan kemudian dipenjarakan.

\section{Bimbingan keagamaan}

Bimbingan keagamaan dilakukan secara intensif oleh pihak dinas sosial, guna untuk menguatkan kembali spiritualitas para gelandangan dan pengemis.

Faktor Pendorong dan Faktor Penghambat Proses Penanganan Gelandangan dan Pengemis di Liponsos

Dalam proses penanganan gelandangan dan pengemis (gepeng), tentu tidak luput dari faktor pendorong dan faktor penghambat. Dan berikut ini adalah faktor pendorong proses penanganan gelandangan dan pengemis (gepeng):

1) Mendapatkan dukungan dari banyak pihak, terutama masyarakat. Seluruh bentuk penanganan yang dilakukan oleh dinas sosial terhadap para gelandangan dan pengemis (gepeng) yang tertampung di Liponsos keputih ini cukup menarik simpati dan dukungan dari banyak pihak, baik dari departemen pemerintahan seperti dinas kesehatan, dinas pertanian dan dinas perikanan maupun lembaga swadaya masyarakat (LSM) yang selalu memberikan dukungan moral maupun material terhadap para gelandangan dan pengemis yang tertampung.

2) Mempunyai pelatih yang sesuai dengan bidangnya. Dalam upaya penanganan gelandangan dan pengemis, pihak dinas sosial telah mendatangkan nara sumber serta pelatih yang sesuai dan berkompeten dibidangnya.

3) Mempunyai ruangan tersendiri untuk melakukan setiap kegiatan. Meskipun ruangan untuk menampung para 
penyandang masalah kesejahteraan sosial (PMKS) sangat terbatas. Akan tetapi Liponsos memiliki sebuah ruangan untuk melakukan kegiatankegiatan yang telah di agendakan oleh pihak dinas sosial.

Sedangkan faktor penghambat proses penanganan gelandangan dan pengemis (gepeng) antara lain adalah sebagai berikut :

1) Terbatasnya jumlah pegawai Dinas Sosial. Dengan jumlah penyandang masalah kesejahteraan sosial (PMKS)

2) Minimnya dana dari pemerintah. Untuk menangani gelandangan dan pengemis yang jumlahnya sangat banyak tersebut diperlukan biaya yang cukup besar.

3) Keadaan panti sosial yang kurang mendukung. Keadaan lingkungan pondok sosial yang kumuh dan kotor tersebut membuat banyak pihak enggan untuk sekedar berkunjung kesana, sehingga lingkungan tidak kondusif dan membuat para penghuni semakin bermalas-malasan dan terbiasa hidup kotor.

Faktor-faktor seseorang memilih untuk menjadi pengemis:

1. Mengemis karena yang bersangkutan tidak berdaya sama sekali dalam segi materi, karena cacat fisik, tidak berpendidikan, tidak punya rumah tetap atau gelandangan, dan orang lanjut usia miskin yang sudah tidak punya saudara sama sekali. Mengemis menjadi bentuk keterpaksaan. Tak ada pilihan lain.

2. Mengemis seperti sudah menjadi kegiatan ekonomi menggiurkan. Mulanya mengemis karena unsur kelangkaan aset ekonomi. Namun setelah beberapa tahun walau sudah memiliki aset produksi atau simpanan bahkan rumah dan tanah dari hasil mengemis tetapi mereka tetap saja mengemis. Jadi alasan mengemis karena tidak memiliki aset atau ketidakberdayaan ekonomi, untuk tipe pengemis ini tidak berlaku lagi. Sang pengemis sudah merasa keenakan. Tanpa rasa malu dan tanpa beban moril di depan masyarakat.

3. Mengemis musiman, misalnya menjelang dan saat bulan ramadhan, hari idul fitri, dan tahun baru. Biasanya mereka kembali ke tempat asal setelah mengumpulkan uang sejumlah tertentu. Namun tidak tertutup kemungkinan terjadinya perubahan status dari pengemis temporer menjadi pengemis permanen.

4. Mengemis karena miskin mental. Mereka ini tidak tergolong miskin sepenuhnya. Kondisi fisik termasuk pakaiannya relatif prima. Namun ketika mengemis, posturnya berubah 180 derajat; apakah dilihat dari kondisi luka artifisial atau baju yang kumel. Maksudnya agar membangun rasa belas kasihan orang lain. Pengemis seperti ini tergolong individu yang sangat malas bekerja. Dan potensial untuk menganggap mengemis sebagai bentuk kegiatan profesinya.

5. Mengemis yang terkoordinasi dalam suatu sindikat. Sudah semacam organisasi tanpa bentuk. Dengan dikoordinasi seseorang yang dianggap bos penolong, setiap pengemis ("anggota") setia menyetor sebagian dari hasil mengemisnya kepada sindikat. Bisa dilakukan harian bisa bulanan. Maka mengemis dianggap sudah menjadi "profesi". Ada semacam pewilayahan operasi dengan anggota-anggota tersendiri.

Untuk menarik simpati banyak orang, pengemis mempunyai cara-cara tersendiri. Ada yang membawa atau menggendong anak kecil entah itu anaknya atau bukan bahkan banyak yang menyewa anak-anak untuk meminta belas kasihan orang-orang, ada yang anggota tubuhnya luka-luka yang 
sesungguhnya maupun luka-luka yang ternyata hanya buatan semata, ada pula yg anggota tubuhnya cacat, ada juga yg 'mengancam' dg menyatakan lebih baik mengemis daripada menjambret, dan masih banyak perilakuperilaku lainnya.

Dalam menentukan atau memilih lokasi mengemis, pengemis memilih tempat yang sudah pasti strategis dekat dengan jangkauan sirkulasi orang yang memilki cukup uang tentunya dan pasti mereka setidaknya dapat mengenali orang orang yang darmawan agar mau menyumbangkan sedikit uangnya. Lokasinya seperti depan tempat ATM, warung, SPBU, Komplek perumahan, depan mall, dan lain lain. Dan tentu saja pengemis mempunyai taktik tertentu untuk mengantipasi dari razia satpol pp ataupun trantip, mereka akan menyiapkan lokasi alternatif sebagai cadangan yang telah disiapkan untuk berjaga-jaga.

Saat melakukan 'misi' nya pengemis ada yang berkelompok maupun individu. Maksudnya berkelompok adalah mereka mempunyai semacam organisasi. Jadi ada seseorang yang memimpin suatu organisasi tersebut. Memimpin dalam arti yaitu memberi pengarahan serta pengalamannya selama menjadi pengemis.

Selain itu pengemis dalam bertutur kata memiliki rasa santun walaupun baju yang mereka pakai compang-camping, tetapi tutur katanya sopan dan agak terlihat kurang mampu. Maksudnya adalah supaya orang yang melihatnya menjadi iba. Setelah ada orang darmawan yang menyumbangkan uangnya pengemis mengucapkan rasa terimakasih ada juga yang membaca doa-doa kebaikan.

Bahkan ada pengemis yang mengemis lebih kepada miskin secara psikologis. Mereka miskin secara psikologis lantaran sebenarnya mampu, tapi menjadikan kegiatan mengemis sebagai mata pencaharian. Kebanyakan pengemis menganggap kalau meminta-minta merupakan suatu perbuatan yang mulia dari pada mencuri. Mereka terus berada dalam pemahaman itu, padahal keliru. Jelas-jelas tangan di atas lebih baik dari pada tangan di bawah.

\section{SIMPULAN DAN REKOMENDASI}

Homeless atau gelandangan adalah orang yang hidup dalam keadaan yang tidak sesuai dengan norma di masayarakat setempat serta tidak mempunyai tempat tinggal yang tetap di wilayah tertentu dan hidup di tempat umum. Penyebab homeless (tunawisma) adalah kemiskinan, kegagalan para perantau dalam mencari pekerjaan, penyediaan lapangan pekerjaan, bencana alam, yatim piatu, kurang kasih sayang, tinggal di daerah konflik, anak yang ditinggalkan orang tuanya, lansia yang ditelantarkan oleh keluarganya, penggusuran karena perkembangan industri, dan pengangguran karena kemajuan iptek akibatnya tenaga kerja kurang terlatih tersingkir sehingga di phk.

Dampaknya ialah kebersihan dan kesehatan yang sangat kurang, gizi kurang, tindak kekerasan sesama tunawisma, penggunaan narkoba, anak-anak yang dimanfaatkan, pelecehan seksual, dll. Kemungkinan yang akan terjadi jika banyak tunawisma tidak segera diatasi ialah akan meningkatkan angka kematian yang disebabkan wabah penyakit, bencana dan angka kriminalitas.

Cara mengatasi permasalahan tersebut yaitu dengan penyuluhan dan konseling, pendidikan pelatihan keterampilan, pengawasan serta pembinaan lanjut, penertiban oleh aparat pemerintah, penampungan di panti asuhan, panti sosial dan panti jompo, rehabilitasi, pembangunan perumahan sangat sederhana, pengadaan rumah singgah dan diberikan pelatihan dan pendidikan, dan transmigrasi.

Selain itu juga memberikan pendidikan agama yang kuat dalam keluarga, menyediakan lapangan pekerjaan yang lebih banyak di kota-kota kecil, rencana oembangunan pemerintah seharusnya mengedepankan pembangunan secara merata, melakukan pembinaan kepada para tunawisma 
melalui panti dan non panti, pelatihan sesuai potensi yang ada, bantuan modal usaha, mengembalikan para tunawisma ke kampong mereka, mengadakan program pendidikan non formal bagi para tunawisma sehingga mereka mendapatkan pengetahuan.

Dan solusi yang paling tepat ialah menyediakan tempat/panti rehabilitasi dimana disana diajarkan keterampilan-keterampilan, menyediakan lapangan-lapangan kerja di kotakota kecil dan menanamkan prinsip "dari kota ke desa".

Dengan melihat arus urbanisasi yang semakin membludak, seharusnya pemerintah lebih memberikan perhatian dengan memberikan penyuluhan bahwa hidup di kota tidak semudah apa yang mereka bayangkan. Selain itu, untuk mengatasi banyaknya tunawisma di sekitar kita, pemerintah harus segera melakukan sesuatu yang dianggap paling efektif. Kendala seperti dana yang relative kecil seharusnya harus dihilangkan. Pemerintah harus mulai memikirkan kesejahteraan rakyat daripada kesejahteraan diri sendiri jika ingin negara ini menjadi negara yang maju.

Penanganan masalah gelandangan dan pengemis ini tidak terlepas dari penanganan kemiskinan itu sendiri, terutama jika dilihat dari sudut pandang daerah asal gepeng. Memang, kemiskinan bukanlah satu-satunya penyebab terjadinya kegiatan menggelandangan dan mengemis tetapi bisa juga menjadi akar penyebab. Oleh karena itu, beberapa alternatif pemecahan masalah yang berkenaan dengan penanganan gepeng dapat ditinjau dari dua aspek, yaitu: (i) kondisi di daerah asal; (ii) kondisi di luar daerah asal. Prinsipnya ialah upaya pencegahan dilakukan di daerah asal sehinggal mereka tidak terdorong untuk meninggalkan desanya dan mencari penghasilan di kota dengan cara mengemis. Sedangkan di sisi lain, prinsipnya ialah penanggulangan di tempat tujuan.

\section{DAFTAR PUSTAKA}

Ramdlon, Naning. S.H. Problema

Gelandangan dalam Tinjauan Tokoh

Pendidikan dan Psikologi. Armico: Bandung.

Sitorus, Santi. 2008. Homeless Sebagai Salah Satu Bentuk Kemiskinan Struktural. Skripsi Sarjana: Jakarta.

Soekanto, Soerjono. 2009. Sosiologi Sebagai Pengantar. Rajawali Pers: Jakarta.

Soetomo. 2008. Masalah Sosial dan Upaya Pemecahannya. Pustaka Pelajar: Yogyakarta.

Waluya, Bagja. 2007. Sosiologi: Menyelami Fenomena Sosial di Masyarakat. PT. Setia Purna Inves: Bandung. 